Article

\title{
Impact of Grain Subsidy Reform on the Land Use of Smallholder Farms: Evidence from Huang-Huai-Hai Plain in China
}

\author{
Xinru Han $\mathbb{D}$, Ping Xue and Ningning Zhang * \\ Institute of Agricultural Economics and Development, Chinese Academy of Agricultural Sciences, \\ Beijing 100081, China; hanxinru@caas.cn (X.H.); 82101201276@caas.cn (P.X.) \\ * Correspondence: zhangningning@caas.cn
}

check for updates

Citation: Han, X.; Xue, P.; Zhang, N. Impact of Grain Subsidy Reform on the Land Use of Smallholder Farms: Evidence from Huang-Huai-Hai Plain in China. Land 2021, 10, 929. https:// doi.org/10.3390/land10090929

Academic Editors: Ana Nieto Masot and José Luis Gurría Gascón

Received: 23 July 2021

Accepted: 31 August 2021

Published: 3 September 2021

Publisher's Note: MDPI stays neutral with regard to jurisdictional claims in published maps and institutional affiliations.

Copyright: (c) 2021 by the authors. Licensee MDPI, Basel, Switzerland. This article is an open access article distributed under the terms and conditions of the Creative Commons Attribution (CC BY) license (https:// creativecommons.org/licenses/by/ $4.0 /)$.
Abstract: Smallholder farms have played an essential role in agricultural production and food security. In order to increase farm size, the Chinese government announced a reform of the grain subsidy program in 2015 . Under the reform, $20 \%$ of the aggregate input subsidy, as well as the pilot subsidy to large-scale farmers and the incremental part of the agricultural support and protection subsidy budget, were used to support increasing farm size. This study evaluated the impact of China's grain subsidy reform on the land use of smallholder farms to investigate whether the reform achieved its goal. Based on 2063 samples obtained from the 2013-2015 Survey for Agriculture and Village Economy data in Huang-Huai-Hai Plain, we conducted a difference-in-difference model to solve the problem of missing counterfactual states in policy evaluation. Farms from Henan and Shandong were assigned to the treatment group, and farms from Hebei were assigned to the control group. The results revealed that the average treatment effect on the treated of the impact of the grain subsidy reform on the wheat-sown area was $-25 \%$ ( $0.10 \mathrm{ha})$. Furthermore, there was heterogeneity in regard to the subsidy reform effects in different sown-area groups. The reform had the most significant impact on the smallest farmers. We also found that China's grain subsidy reform had a significant and positive effect on the amount of outflow land area, while the impact of subsidy reform on land tenure was insignificant. Our findings suggest that while encouraging large-scale farms, it is necessary to take into account farmers' small-scale operations and gradually promote the transformation of small-scale operations to large-scale operations. The Chinese government should strengthen the supervision of land use to achieve the goal of ensuring food security.

Keywords: agriculture subsidy program; land use; farm size; difference-in-difference

\section{Introduction}

Food security is the 2nd Sustainable Development Goal (SDG2) and a key objective of the Chinese agricultural policy [1,2]. Smallholder farms have played an essential role in agricultural production and food security, especially in Asian countries [3-5]. In China, the average farm size is only 0.52 ha, and nearly $98 \%$ of farms are smaller than 2 ha $[3,6]$. Recently, several efforts have been undertaken by the Chinese government to encourage the farms to expand to increase farm output efficiency, reduce production costs, and reduce the use of agricultural chemicals [7-11].

Previous studies have shown that subsidy programs, e.g., direct payments, are efficient tools to achieve policy goals [12-15]. Since the commencement of the country's first grain subsidy program in 2004, China's grain output has increased dramatically, reaching 663.84 million tons in 2019, with an annual growth rate of 2.3\% [16]. Meanwhile, China's Producer Support Estimate (PSE) has increased from 170.9 billion CNY in 2004 to 1.4 trillion CNY in 2016 [17].

China launched its grain subsidy program in 2004 to increase grain production and farmers' incomes [18-20]. The program consisted of direct grain subsidy, quality 
seed subsidy, and machinery subsidy [18,21,22]. Later in 2006, the aggregate input subsidy was introduced to the grain subsidy program when fertilizer and fuel prices rose rapidly $[18,19,21,23]$. The direct grain subsidy, the quality seed subsidy, and the aggregate input subsidy (also known as the "three subsidies") were wired to farmers" bank accounts mainly based on the grain-sown areas [21,23]. This machinery subsidy was only available to those who purchased medium or large machines, and approximately $30-50 \%$ of the subsidy value was deducted from the cost of these machines [23]. The subsidy amount was $1425 \mathrm{CNY} / \mathrm{ha}$ in 2012 , and an average Chinese farm could only receive $741 \mathrm{CNY} / \mathrm{ha}$, about $6.7 \%$ of its annual income [23].

In 2015, the Ministry of Finance (MOF) and the Ministry of Agriculture (MOA) announced a reform of the grain subsidy program through combining the direct grain subsidy, the quality seed subsidy, and the aggregate input subsidy into an "agricultural support and protection subsidy". To actively and steadily promote the grain subsidy reform, the MOF and MOA selected Anhui, Shandong, Hunan, Sichuan, and Zhejiang as the reform pilot provinces in 2015 [24]. The Henan province, however, also reformed the grain subsidy based on the announcement issued by the MOF and MOA in 2015 [25]. Then, the reform has been implemented nationwide since 2016. The reform aims were set to improve the accuracy of subsidy, strengthen the protection of arable land, and increase farm size [24]. Furthermore, the agricultural support and protection subsidy is still a planted-area-based subsidy based on hectares planted to grain [26]. In particular, Shandong Province, one of the pilot provinces, addressed that the subsidy would be paid according to the area of wheat sown [27].

Under the reform, $20 \%$ of the aggregate input subsidy, as well as the pilot subsidy to large-scale farmers and the incremental part of the agricultural support and protection subsidy budget, were used to support increasing farm size. Furthermore, the subsidy targets included large-scale farms, large-scale family farms, farmer cooperatives, and agricultural socialization service organizations. The government also announced a slogan; whoever has a higher grain production would receive priority support of subsidy fund. Additionally, $80 \%$ of the aggregate input subsidy, as well as the direct grain subsidy and the quality seed subsidy were used to protect arable land and increase land productivity. In 2016, the total amount of "agricultural support and protection subsidy" reached 144.2 billion CNY, including 23.8 billion CNY to increase farm size [28].

Moreover, as designed by the policymakers, smallholder farms would receive fewer subsidies, while subsidy amounts for large-scale and cooperative farming would increase. Consequently, the reform may have two opposing impact pathways. Firstly, smallholder farms would increase their farm size to receive more subsidies. Secondly, smallholders might transfer their lands to large-scale farmers or cooperatives so as to decrease or terminate their grain production.

Previous studies on the China's grain subsidy effects mainly focused on production [29-32], migration [33,34], effectiveness [26,35], and welfare [18,29,32,36]. Some studies also shed light on the relationship between China's agricultural subsidy and land use. For instance, Yi et al. (2015) concluded that the grain subsidy program had a positive effect on grain-sown areas [23]. Zou et al. (2020) found that the grain subsidy had a significant and positive effect on both leasing out and leasing in farmland in rural China [37]. Guo et al. (2021) concluded that an increase in soybean producer subsidy would encourage farmers to allocate more land for soybean planting [38]. Additionally, since grain subsidies might increase land tenure [39], the grain subsidies were paid mostly to the land contractor instead of the operator [31,37], and farm size was found to have a significantly negative effect on land tenure [39]. Huang et al. (2011) demonstrated that the grain subsidy policy did not affect their grain production decisions [31]. However, to our knowledge, previous studies have rarely empirically explored whether China's grain subsidy reform achieved its goal to increase farm size. This study contributes to the literature by providing evidence on the relationship between the subsidy reform and the land use of smallholder farms 
and reveals the impact pathways of the reform. Our results also have important policy implications to further improve China's grain subsidy programs.

The main challenge in empirically evaluating policy impacts is to determine how to address missing counterfactual states, because we observe what happens to them with treatment, but we cannot observe what would have happened without treatment [40]. In practice, propensity score matching (PSM) [41-43], regression discontinuity designs (RDD) [44,45], and difference-in-difference (DID) [46-51] are the most common approaches used for counterfactual analysis. However, PSM is mainly used to correct selection bias [41], and RDD can be applied when policy leads to the cut-off for key explanatory variables [45]. In this study, since the subsidy reform was exogenously issued by the government and covered each farm in the pilot provinces, selection bias would not occur, and the reform would not bring any cut-offs. We thus adopted the DID approach to evaluate the impacts of China's grain subsidy reform on the land use of smallholder farms, the heterogeneity across different farm-size groups, and the potential impact pathways of the reform.

\section{Materials and Methods}

\subsection{Study Area}

Huang-Huai-Hai Plain is one of the most productive grain belts, especially winter wheat growing areas in China (Figure 1) [52,53]. In 2019, Huang-Huai-Hai Plain produced $23.8 \%$ of China's grain and $58.1 \%$ of China's wheat [16]. Furthermore, two pilot provinces implemented a subsidy reform in 2015, i.e., Shandong and Henan, located at the HuangHuai-Hai Plain. To evaluate the impact of China's grain subsidy reform, farms should be assigned either to the treatment group or to the control group. First, farms from Henan and Shandong were subjected to the reform, and were therefore assigned to the treatment group. Second, we selected the farms in the Hebei Province as the control group since the province lies on the Huang-Huai-Hai Plain, but has not reformed the grain subsidy until 2016.

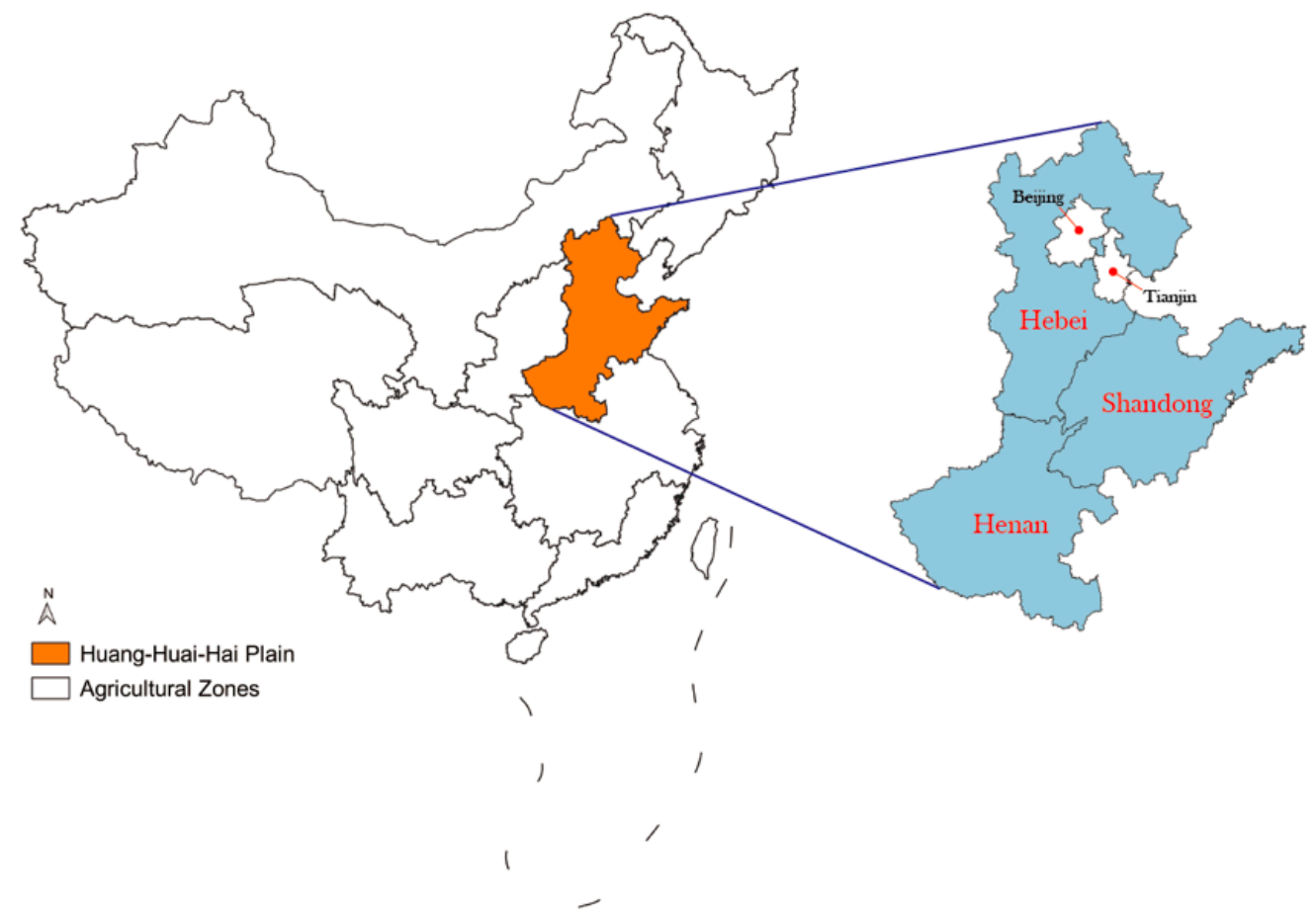

Figure 1. The geographical location of the study areas. 


\subsection{Experimental Design}

\subsubsection{Empirical Method}

This study employs a difference-in-difference (DID) approach to evaluate the impacts of China's grain subsidy reform on the land use of smallholder farms. As shown in Figure 2, the first difference is the difference between post- and pre-treatment in the treatment group $(A 2-A 1)$, and the second difference is the difference between post- and pre-treatment in the control group $(B 2-B 1)$. The impact of treatment on the outcome of interest is $(A 2-A 1)-(B 2-B 1)$.

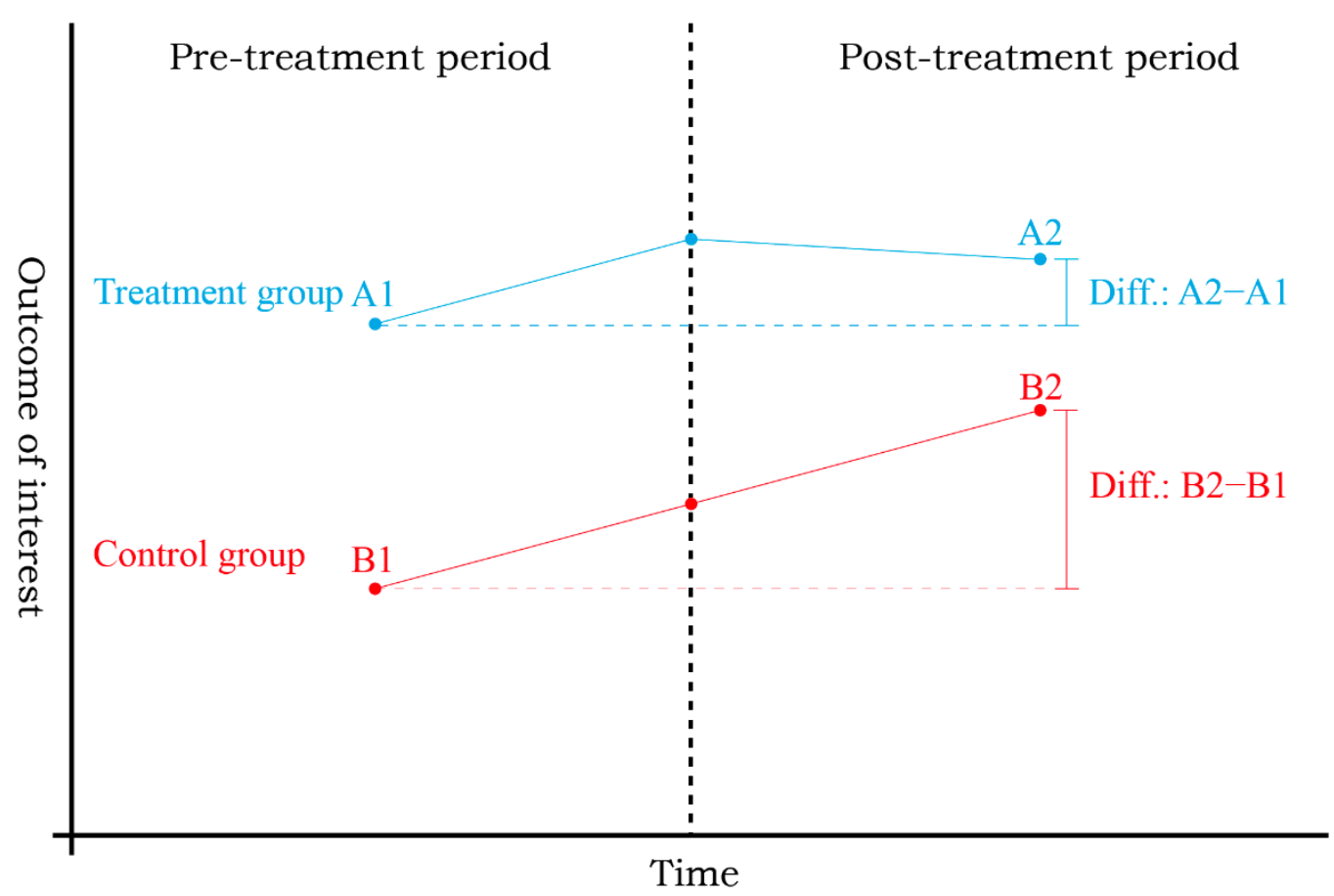

Figure 2. Conceptual illustration of the DID approach.

Let $Y_{i t}$ be the outcome of interest for farm $i$ at time $t$. The naive difference-in-differences estimator is described as the following regression:

$$
y_{i t}=\alpha+\beta\left(D_{i} \times T_{t}\right)+\gamma D_{i}+\delta T_{t}+\varepsilon_{i t}
$$

where $D_{i}$ is an indicator variable equal to 1 if farm $i$ has been exposed to the treatment (e.g., policy reform) and 0 otherwise; $T_{t}$ is a time-specific component; $t=0$ if the population is observed in a pre-treatment period, and $t=1$ in a post-treatment period; $\alpha$ is a constant; $\beta$ captures the average treatment effect on the treated (ATET), which is $(A 2-A 1)-(B 2-B 1)$ in Figure 2 and the focus of policy evaluation; $\gamma$ and $\delta$ are other parameters to be estimated; $\varepsilon_{i t}$ represents the random error item. Therefore, the DID procedure removed a large degree of the potential for biases attributable to unobservable heterogeneity and omitted variables $[46,54]$.

In our study, the outcome variable is the wheat-sown areas $\left(W A_{i t}\right)$ due to the following two reasons. First, the subsidy was allocated based on the wheat-sown areas in the Shandong province [27], which indicated that farms could receive more subsidies if they enlarged their wheat-sown areas. Second, since the reform announcement was issued in May 2015 by the central government, in June 2015 by the Shandong province, and in August 2015 by the Henan province, respectively, only winter crops (i.e., winter wheat in the Huang-Huai-Hai Plain) could be affected by the reform $[24,25,27]$. Further, we used the logarithm form of wheat-sown areas to obtain the percentage changes in wheat-sown areas. Additionally, since the subsidy reform was piloted in 2015 and implemented nationwide in 2016, we denoted $t=0$ if $T<2015$, and $t=1$ if $T=2015$. We also added a group of control 
variables $\left(x_{i t j}\right)$ that affect wheat-sown area to Equation (1). Based on the previous literature, the $x_{i t j}$ include labor and tractor input, land tenure, and individual characteristics of the household heads (HHs), such as the age, years of education, and agricultural training. Thus, Equation (1) can be revealed as the following:

$$
\ln W A_{i t}=\alpha+\beta\left(D_{i} \times T_{t}\right)+\gamma D_{i}+\delta T_{t}+\sum_{j=1}^{n} \gamma_{j} x_{i t j}+\varepsilon_{i t}
$$

where $n$ is the number of the control variables and $\gamma_{j}$ are the parameters to be estimated. One of the main assumptions to estimate the DID model is parallel trends [55]. Under the parallel trends assumption, trends in outcomes between the treatment and control groups are the same prior to the implementation of the subsidy reform [46].

\subsubsection{Data Collection}

Data used in this study were obtained from the 2013-2015 Survey for Agriculture and Village Economy (SAVE), which is an annual rural household survey conducted by the Institute of Agricultural Economics and Development (IAED), the Chinese Academy of Agricultural Sciences (CAAS) [43]. We select an unbalanced panel sample from 93 villages in 9 counties in Hebei (the counties of Pingshan, Luannan, and Qiu), Shandong (the counties of Qixia, Shouguang, and Gaotang), and Henan (the counties of Fan, Xuchang, and Queshan) provinces (Figure 3).

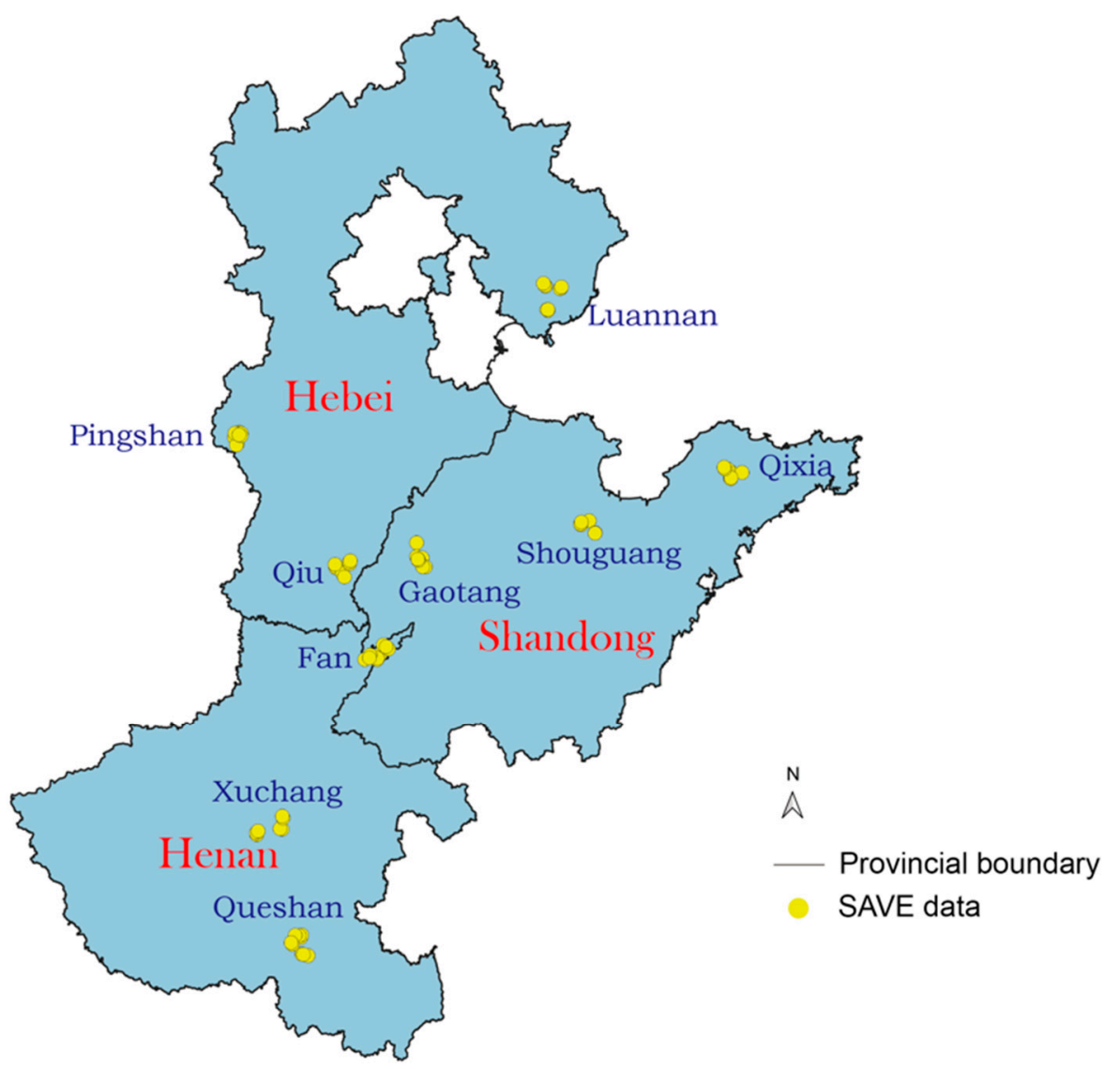

Figure 3. The geographical location of the samples.

Before estimation, the data were processed as follows. (1) The variables related to price were processed using the national Consumer Price Index $(\mathrm{CPI}, 2012=100)$ to eliminate the effect of inflation. (2) Only farms with a wheat-sown area greater than 0 and less than 2 ha (the threshold of smallholder farm) were kept. (3) To reflect the opportunity cost of land transfer, missing values for land tenure were replaced with the provincial median in the same year. (4) To exclude the effect of machinery subsidy, the households that purchased 
agricultural machinery in the survey year were removed. After data processing, 2063 valid samples were retained, and 1550 were treated (Table A1).

\section{Results}

\subsection{Descriptive Analysis}

As shown in Table 1, the average wheat-sown area in the sample regions was only 0.39 ha. The average subsidy farmer received and land tenure were 1847.28 CNY/ha and 2742.87 CNY/ha, respectively. Further, since labor is still essential in China's wheat production, the average labor input reached 71.38 days/ha, while only $34 \%$ of farms own at least one tractor. In terms of individual characteristics of the household heads (HHs), most wheat farmers were aged, less-educated, and none-trained. The average age reached 52.51 , while the average years of education of wheat farmers were only 7.83. Lastly, only $34 \%$ of wheat farmers in the survey received agricultural training.

Table 1. Summary statistics of variables.

\begin{tabular}{|c|c|c|c|c|}
\hline Variable & Mean & SD & MAX & MIN \\
\hline \multicolumn{5}{|c|}{ Panel A: All farms } \\
\hline WA: Wheat-sown area (ha) & 0.39 & 0.24 & 2.00 & 0.03 \\
\hline SUB: Subsidy (CNY/ha) & 1847.28 & 517.47 & 4425.00 & 719.82 \\
\hline LAND: Land tenure (CNY/ha) & 2742.87 & 313.97 & 7037.30 & 718.09 \\
\hline LB: Labor input (Days/ha) & 71.38 & 45.25 & 242.92 & 18.75 \\
\hline TRAC: Tractor ownership $(1=\mathrm{Y}, 0=\mathrm{N})$ & 0.37 & 0.48 & 1.00 & 0.00 \\
\hline$A G E:$ Age of $\mathrm{HH}$ & 52.51 & 10.62 & 88.00 & 19.00 \\
\hline EDU: Education of $\mathrm{HH}$ (Years) & 7.83 & 2.61 & 16.00 & 0.00 \\
\hline AGT: Agricultural training $(1=\mathrm{Y}, 0=\mathrm{N})$ & 0.34 & 0.47 & 1.00 & 0.00 \\
\hline Number of observations $(\mathrm{N})$ & 2063 & & & \\
\hline \multicolumn{5}{|c|}{ Panel B: Farms in the treatment group (Henan and Shandong) } \\
\hline WA: Wheat-sown area (ha) & 0.40 & 0.25 & 2.00 & 0.03 \\
\hline SUB: Subsidy (CNY/ha) & 1795.73 & 413.67 & 4125.00 & 720.00 \\
\hline LAND: Land tenure (CNY/ha) & 2731.28 & 319.26 & 7037.30 & 718.09 \\
\hline LB: Labor input (Days/ha) & 73.23 & 48.71 & 242.92 & 18.75 \\
\hline TRAC: Tractor ownership $(1=\mathrm{Y}, 0=\mathrm{N})$ & 0.33 & 0.47 & 1.00 & 0.00 \\
\hline$A G E:$ Age of $\mathrm{HH}$ & 52.93 & 10.41 & 88.00 & 19.00 \\
\hline EDU: Education of $\mathrm{HH}$ (Years) & 7.71 & 2.80 & 16.00 & 0.00 \\
\hline AGT: Agricultural training $(1=\mathrm{Y}, 0=\mathrm{N})$ & 0.32 & 0.47 & 1.00 & 0.00 \\
\hline Number of observations $(\mathrm{N})$ & 1550 & & & \\
\hline \multicolumn{5}{|c|}{ Panel C: Farms in the control group (Hebei) } \\
\hline WA: Wheat-sown area (ha) & 0.34 & 0.20 & 1.67 & 0.04 \\
\hline SUB: Subsidy (CNY/ha) & 2003.02 & 726.87 & 4425.00 & 719.82 \\
\hline LAND: Land tenure (CNY/ha) & 2777.87 & 294.95 & 5654.27 & 807.75 \\
\hline$L B:$ Labor input (Days/ha) & 65.79 & 32.02 & 240.00 & 18.75 \\
\hline TRAC: Tractor ownership $(1=\mathrm{Y}, 0=\mathrm{N})$ & 0.48 & 0.50 & 1.00 & 0.00 \\
\hline$A G E:$ Age of $\mathrm{HH}$ & 51.26 & 11.15 & 79.00 & 25.00 \\
\hline EDU: Education of $\mathrm{HH}$ (Years) & 8.19 & 1.90 & 12.00 & 0.00 \\
\hline AGT: Agricultural training $(1=\mathrm{Y}, 0=\mathrm{N})$ & 0.40 & 0.49 & 1.00 & 0.00 \\
\hline Number of observations $(\mathrm{N})$ & 513 & & & \\
\hline
\end{tabular}

Compared with the control group, farms in the treatment group had significant characteristics (Table 2). First, the wheat-sown area of farms in the treatment group was 0.07 ha (or 19.5\%) larger than that of the farms in the control group. Second, subsidy and land tenure per area in the treatment group were $207.29 \mathrm{CNY} /$ ha (or 10.3\%) and $46.59 \mathrm{CNY} / \mathrm{ha}$ (or 1.7\%) less of that of the control group, respectively. Third, farms in the treatment group tended to input more labor other than buy tractors. Fourth, HHs in the treatment group were significantly older than those of the control group, while the education level and agricultural training participation of HHs was significantly less than those of the control group. 
Table 2. Differences of variables between the treatment and control groups.

\begin{tabular}{|c|c|c|}
\hline Variable & $\begin{array}{l}\text { Diff. in Means } \\
\text { Mean }_{\mathrm{T}}-\text { Mean }_{\mathrm{C}}\end{array}$ & $\begin{array}{c}\text { Diff. } \% \\
\left(\operatorname{Mean}_{\mathrm{T}}-\text { Mean }_{\mathrm{C}}\right) / \text { Mean }_{\mathrm{T}}\end{array}$ \\
\hline WA: Wheat-sown area (ha) & 0.07 * & $19.4 \%$ \\
\hline SUB: Subsidy (CNY/ha) & $-207.29 *$ & $-10.3 \%$ \\
\hline$L A N D$ : Land tenure (CNY/ha) & $-46.59 *$ & $-1.7 \%$ \\
\hline LB: Labor input (Days/ha) & $7.44 *$ & $11.3 \%$ \\
\hline TRAC: Tractor ownership $(1=\mathrm{Y}, 0=\mathrm{N})$ & $-0.15^{*}$ & $-31.3 \%$ \\
\hline$A G E:$ Age of $\mathrm{HH}$ & 1.67 * & $3.3 \%$ \\
\hline EDU: Education of $\mathrm{HH}$ (Years) & $-0.48 *$ & $-5.9 \%$ \\
\hline AGT: Agricultural training $(1=\mathrm{Y}, 0=\mathrm{N})$ & $-0.08 *$ & $-20.0 \%$ \\
\hline
\end{tabular}

Notes: Mean $_{\mathrm{T}}$ and Mean $\mathrm{C}_{\mathrm{C}}$ indicates means in the treatment group and control group, respectively; ${ }^{*} p<0.05$ based on the $t$ test.

After the subsidy reform (Table 3), wheat farms did not significantly change their wheat-sown area, although the subsidy was $62.96 \mathrm{CNY} /$ ha (or 3.3\%) less than before, and the land tenure per area was $343.95 \mathrm{CNY} /$ ha (or 13.1\%) more than before. Furthermore, compared with the pre-treatment group, farms significantly decreased their labor input but increased their machine input in wheat production.

Table 3. Differences of variables between the pre- and post-treatment groups.

\begin{tabular}{|c|c|c|}
\hline Variable & $\begin{array}{l}\text { Diff. in Means } \\
\text { Mean }_{\mathrm{Pt}}-\text { Mean }_{\mathrm{Pr}}\end{array}$ & $\begin{array}{c}\text { Diff. } \% \\
\left(\text { Mean }_{\mathrm{Pt}}-\text { Mean }_{\mathrm{Pr}}\right) / \mathrm{Mean}_{\mathrm{Pr}}\end{array}$ \\
\hline WA: Wheat-sown area (ha) & 0.06 & $15.8 \%$ \\
\hline SUB: Subsidy (CNY/ha) & $-62.96 *$ & $-3.3 \%$ \\
\hline LAND: Land tenure (CNY/ha) & $343.95 *$ & $13.1 \%$ \\
\hline LB: Labor input (Days/ha) & $-12.86 *$ & $-17.0 \%$ \\
\hline TRAC: Tractor ownership $(1=\mathrm{Y}, 0=\mathrm{N})$ & $0.02 *$ & $5.6 \%$ \\
\hline$A G E:$ Age of $\mathrm{HH}$ & 0.69 & $1.3 \%$ \\
\hline EDU: Education of $\mathrm{HH}$ (Years) & 0.08 & 1.0 \\
\hline AGT: Agricultural training $(1=\mathrm{Y}, 0=\mathrm{N})$ & -0.11 & -29.2 \\
\hline
\end{tabular}

Notes: Mean ${ }_{\mathrm{Pt}}$ and Mean $\mathrm{Pr}$ indicates means in the post- and pre-treatment groups, respectively; ${ }^{*} p<0.05$ based on the $t$ test.

\subsection{DID Results}

We empirically analyzed the impact of the grain subsidy reform on the wheat-sown area based on a DID approach. Since the samples are clustered (Figure 3), we applied a clustered ordinary least squares (OLS) estimation strategy to obtaining robust variance estimates. Based on Equations (1) and (2), we added the control variables step by step and arranged the estimation results in Table 4.

The most important finding of our results is that China's grain subsidy reform significantly, but negatively, affects smallholder farms' wheat-sown area in the Huang-Huai-Hai Plain. Controlling the characteristic variables (columns 3 (DID3) in Table 4), the ATET of the impact of the grain subsidy reform on the wheat-sown area was $-25 \%$. It indicates that after the grain subsidy reform, a smallholder farm would reduce $25 \%$ ( $0.10 \mathrm{ha}$ ) of its wheat-sown area. Further, it is not a surprise that labor input negatively affects the wheat-sown area, while tractor ownership positively affects the wheat-sown area. The relationship between the age of HHs and wheat-sown area shows an inverse "U-shape", while there is a "U-shape" relationship between the education level of HHs and wheat-sown area. Agricultural training, however, had no significant effect on the wheat-sown area. 
Table 4. Estimation results of the DID models.

\begin{tabular}{|c|c|c|c|}
\hline Variable & $\begin{array}{l}\text { DID1 } \\
\text { (1) }\end{array}$ & $\begin{array}{l}\text { DID2 } \\
(2)\end{array}$ & $\begin{array}{l}\text { DID3 } \\
\text { (3) }\end{array}$ \\
\hline \multicolumn{4}{|c|}{ Dependent variable: $\ln W A$} \\
\hline$D_{i} \times T_{t}$ & $\begin{array}{c}-0.16^{*} \\
(0.08)\end{array}$ & $\begin{array}{c}-0.26^{* *} \\
(0.08)\end{array}$ & $\begin{array}{c}-0.25^{* *} \\
(0.08)\end{array}$ \\
\hline$D_{i}$ & $\begin{array}{c}0.22 \\
(0.12)\end{array}$ & $\begin{array}{c}0.29 * * \\
(0.09)\end{array}$ & $\begin{array}{l}0.28 \text { ** } \\
(0.08)\end{array}$ \\
\hline$T_{t}$ & $\begin{array}{l}0.15^{*} \\
(0.07)\end{array}$ & $\begin{array}{l}0.15 \text { * } \\
(0.06)\end{array}$ & $\begin{array}{l}0.16 \text { * } \\
(0.06)\end{array}$ \\
\hline $\ln W A$ & & $\begin{array}{c}-0.31^{* * *} \\
(0.05)\end{array}$ & $\begin{array}{c}-0.30 * * * \\
(0.05)\end{array}$ \\
\hline$T R A C$ & & $\begin{array}{c}0.24^{* * *} \\
(0.06)\end{array}$ & $\begin{array}{l}0.22 * * \\
(0.06)\end{array}$ \\
\hline$A G E$ & & & $\begin{array}{l}0.03 \text { * } \\
(0.01)\end{array}$ \\
\hline$A G E^{2}$ & & & $\begin{array}{c}-0.00^{* *} \\
(0.00)\end{array}$ \\
\hline$E D U$ & & & $\begin{array}{c}-0.06 \text { * } \\
(0.02)\end{array}$ \\
\hline$E D U^{2}$ & & & $\begin{array}{l}0.00 \text { ** } \\
(0.00)\end{array}$ \\
\hline$A G T$ & & & $\begin{array}{c}0.08 \\
(0.06)\end{array}$ \\
\hline Constant term & $\begin{array}{c}1.42^{* * *} \\
(0.09)\end{array}$ & $\begin{array}{c}1.73 * * * \\
(0.12)\end{array}$ & $\begin{array}{c}1.13^{* * *} \\
(0.29)\end{array}$ \\
\hline $\mathrm{N}$ & 2063 & 2063 & 2063 \\
\hline
\end{tabular}

Notes: Cluster robust (town level) standard errors in parentheses; ${ }^{* * *} p<0.01,{ }^{* *} p<0.05,{ }^{*} p<0.10$.

\subsection{Parallel Trends Test}

The time trend graph of the averages of the logarithmic values for the wheat-sown area is shown in Figure 4. In the 2013-2014 period, the trends for the treatment group and control group were essentially consistent in terms of the average logarithmic values for the wheat-sown area, exhibiting an upward trend. However, in the 2014-2015 period, the two groups showed different trends. The wheat-sown area for the treatment group showed a downward trend, which was consistent with the model estimation results, while the wheat-sown area for the control group showed an upward trend. The above analysis indicates that the model passed the parallel trend test.

\subsection{Robustness Test}

We first tested the robustness of the model estimation results by varying the control variables; the results are shown in Table 4 . In columns 1 (DID1), we focus on the naive difference-in-differences estimators following Equation (1). Then, as shown in columns 2 (DID2), we added input variables (i.e., labor and tractor) to the naive model. Finally, we added all of the control variables. The results show that the coefficients of $D_{i} \times T_{t}$ are significant and the values are similar in all of the three models, indicating that the estimated results of this study have strong robustness.

Second, although the DID approach can eliminate geographical factors that do not change over time, our study area is too wide to control the time-variant geographical factors such as precipitation and drought. Thus, we narrowed the samples to three neighboring counties, Gaotang, Fan, and Qiu (Figure 3). The DID estimation results (columns 1 (DID4) in Table A2) suggest that the ATET of the impact of the grain subsidy reform on the wheat-sown area in the three neighboring counties is $-28 \%$, whose absolute value is three percentage points larger than the absolute value of the ATET in columns 3 (DID3) in Table 4. The results also support the robustness of our study. 


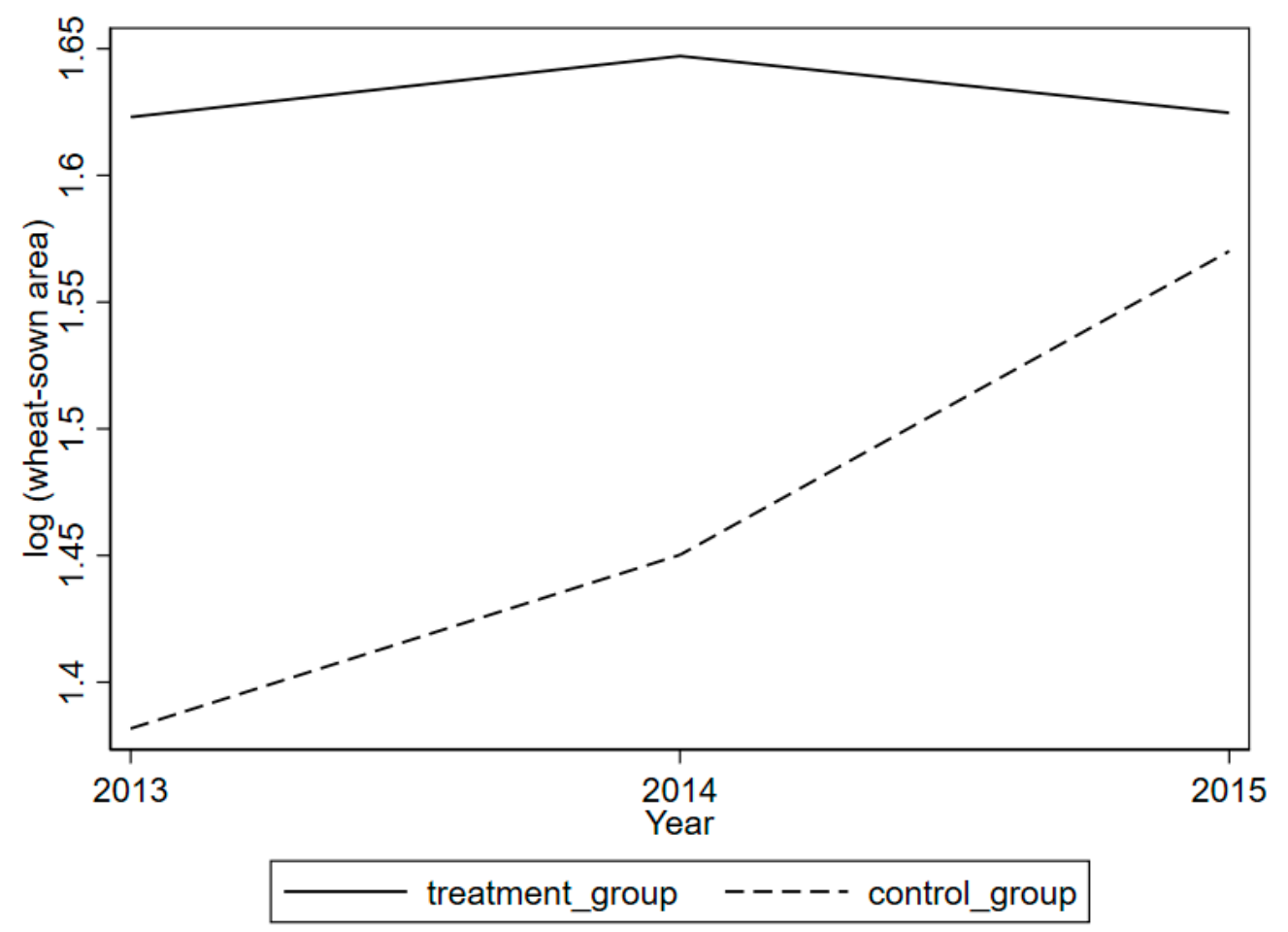

Figure 4. Result of parallel trends test.

Third, we compared our DID estimation results with the OLS model and fixed effects (FE) model using a dummy variable for the year 2015 ( $T_{t}$ in the DID model) as the proxy of reform. The dependent variable and control variables are the same as the DID model. The results listed in columns 2 (OLS) and columns 3 (FE) in Table A2 show that the coefficients of $T_{t}$ are not significant. Considering the influence of unobserved factors that may lead to the endogeneity problem, the results of the OLS model and FE model are biased and unreliable.

\subsection{Heterogeneity Effect}

To further examine the heterogeneous effect of the subsidy reform on the wheat-sown area of farmers, we divided the wheat-sown area into three categories based on wheat-sown area $33 \%, 66 \%$, and $100 \%$ percentiles. The threshold was 0.27 ha and 0.40 ha, respectively. Thus, the three categories were (1) Cat1: $0<W A<0.27$; (2) Cat2: $0.27 \leq W A<0.40$; and (3) Cat3: $0.40 \leq W A \leq 2$ (the unit of $W A$ is ha). The DID estimation results for the three wheat-sown area categories are shown in Table 5.

The results suggest that the subsidy reform had a significantly negative effect on farmers in Cat1 and Cat2, but no significant impact on those in Cat3. Specifically, the ATET of subsidy reform on farms in Cat1 and Cat 2 was $-9 \%$ and $-4 \%$, respectively. The results indicate that the effect of China's grain subsidy reform decreases as the wheat-sown area increases.

Table 5. Estimation results of the DID models for different wheat-sown area categories.

\begin{tabular}{cccc}
\hline Variable & $\begin{array}{c}\text { Cat } \mathbf{1} \\
\mathbf{( 1 )}\end{array}$ & $\begin{array}{c}\text { Cat 2 } \\
\mathbf{( 2 )}\end{array}$ & $\begin{array}{c}\text { Cat 3 } \\
\mathbf{( 3 )}\end{array}$ \\
\hline Dependent variable: lnWA & & & \\
$D_{i} \times T_{t}$ & $-0.09 *$ & -0.04 & -0.11 \\
& $(0.04)$ & $(0.02)$ & $(0.06)$ \\
$D_{i}$ & -0.01 & 0.00 & 0.05 \\
& $(0.07)$ & $(0.04)$ & $(0.06)$ \\
\hline
\end{tabular}


Table 5. Cont.

\begin{tabular}{|c|c|c|c|}
\hline Variable & $\begin{array}{c}\text { Cat } 1 \\
\text { (1) }\end{array}$ & $\begin{array}{c}\text { Cat } 2 \\
(2)\end{array}$ & $\begin{array}{c}\text { Cat } 3 \\
\text { (3) }\end{array}$ \\
\hline$T_{t}$ & $\begin{array}{l}0.05 * \\
(0.02)\end{array}$ & $\begin{array}{c}0.02 \\
(0.01)\end{array}$ & $\begin{array}{l}0.10 * \\
(0.04)\end{array}$ \\
\hline $\operatorname{lnWA}$ & $\begin{array}{c}-0.11^{* *} \\
(0.04)\end{array}$ & $\begin{array}{c}-0.03 \text { * } \\
(0.01)\end{array}$ & $\begin{array}{c}0.10 \\
(0.04)\end{array}$ \\
\hline$T R A C$ & $\begin{array}{c}0.15^{* * * *} \\
(0.03)\end{array}$ & $\begin{array}{c}0.02 \\
(0.02)\end{array}$ & $\begin{array}{l}-0.08 \\
(0.04)\end{array}$ \\
\hline$A G E$ & $\begin{array}{l}-0.00 \\
(0.01)\end{array}$ & $\begin{array}{l}0.01 \text { * } \\
(0.00)\end{array}$ & $\begin{array}{c}0.05 \\
(0.05)\end{array}$ \\
\hline$A G E^{2}$ & $\begin{array}{l}-0.00 \\
(0.00)\end{array}$ & $\begin{array}{l}-0.00 \\
(0.00)\end{array}$ & $\begin{array}{c}-0.00 \text { * } \\
(0.00)\end{array}$ \\
\hline$E D U$ & $\begin{array}{l}-0.03 \\
(0.02)\end{array}$ & $\begin{array}{l}-0.00 \\
(0.01)\end{array}$ & $\begin{array}{c}-0.04 \text { * } \\
(0.02)\end{array}$ \\
\hline$E D U^{2}$ & $\begin{array}{l}-0.00 \\
(0.00)\end{array}$ & $\begin{array}{c}0.00 \\
(0.00)\end{array}$ & $\begin{array}{l}0.00 * \\
(0.00)\end{array}$ \\
\hline$A G T$ & $\begin{array}{l}-0.01 \\
(0.05)\end{array}$ & $\begin{array}{c}0.00 \\
(0.02)\end{array}$ & $\begin{array}{l}0.06^{* *} \\
(0.02)\end{array}$ \\
\hline Constant term & $\begin{array}{c}1.45^{* * *} \\
(0.33)\end{array}$ & $\begin{array}{c}1.37^{* * *} \\
(0.10)\end{array}$ & $\begin{array}{c}1.65^{* * *} \\
(0.39)\end{array}$ \\
\hline $\mathrm{N}$ & 765 & 645 & 653 \\
\hline
\end{tabular}

\section{Discussion}

Increasing farm size was one of the aims of China's grain subsidy reform in 2015. Results show that smallholder farms significantly changed land use by decreasing wheat production in Huang-Huai-Hai Plain instead of increase their farm size to receive more subsidies. We also found that the reform has the greatest impact on the smallest farmers. These results indicate that there is a positive relationship between subsidy amount and grain-sown areas. Our findings are consistent with those of Yi et al. (2015) [23], Zou et al. (2020) [37], and Guo (2021) [38], but different from those of Gale et al. (2005) [22] and Huang et al. (2011) [31].

The empirical results have important policy implications for promoting grain subsidy policy reform and ensuring China's food security. First, China's grain subsidy reform has reduced the wheat-sown area of smallholder farms. Although this reform was purported to increase farm size, it is still necessary to take into account the basic national condition that China is a "large country with smallholder farms" and the reality that smallholder farms are the primary business entity in farming. Therefore, while encouraging large-scale farms, it is necessary to take into account farmers' small-scale operations and gradually promote the transformation of small-scale operations to large-scale operations.

From the perspective of international comparability, previous studies have shown that the reduction in subsidy or similar reforms would lead to a decline in land use. For instance, Ciaian (2007) and Helming and Tabeau (2018) found that the reduction in the Pillar I budget of the Common Agricultural Policy (CAP) of the European Union (EU) led to a decrease in utilised agricultural area [56,57]; Tranter et al. (2007) and Tzanopoulos et al. (2012) found that the 2003 CAP reforms, which decoupled of support payments from production decisions, led to a decline in the cereal and oilseed production area $[58,59]$. Tranter et al. (2007) also pointed out that farmers would like to transfer to produce forestry, woodland, and non-food crops [59]. In the United States, cropland acreage would also decrease if the payments of Farm Commodity Programs payments had been reduced [60]. Since China continues its reform in grain subsidy [18,61], those studies can also provide strong evidence about the potential impacts of subsidy reform to China's policymakers.

To further investigate whether smallholder farms transferred their land out, we estimated a naive DID model based on Equation (1). The dependent variable is the amount of outflow land area. The results show that China's grain subsidy reform has a significant and 
positive effect on the amount of outflow land area (Table A3). Thus, the impact pathway of China's grain subsidy reform is that smallholders might transfer their lands to large-scale farmers or cooperatives so as to decrease or terminate their grain production.

Previous studies found that if the smallholder farms transfer their lands to large farms, the land tenure increased accordingly [39,62]. We used another naive DID model to reveal the relationship between subsidy reform and land tenure (Table A3). The results show that the impact of subsidy reform on land tenure is insignificant, which is consistent with Lin and Huang (2021)'s study [63]. However, considering the evidence found by Tranter et al. (2007) [59] and the low ratio of profits to cost and expense in wheat production (1.77, $-8.11,0.61$, and -15.74 in 2015-2018, respectively [64]), large farms may change the land use from producing wheat to cash crops or vegetables. Thus, the Chinese government should strengthen the supervision of land use to achieve the goal of ensuring food security. Furthermore, policymakers are suggested to improve the land rental market environment to protect the interests of smallholder farms.

There are several limitations to our study. First, since only a few samples in the SAVE data that we used are large farms, we only examined the effect of the subsidy reform on the land use behavior of smallholder farms. Therefore, the application of the results of this study is limited, and the impact of the policy reform on land use of large-scale farms is still unknown. Furthermore, whether large-scale farms continue producing grain is essential to China's food security. Second, limited by the unbalanced panel data, we could not investigate if the number of smallholders was decreasing or not after the reform. Third, as some farms do not transfer their lands, we could not further investigate how the land is used after farms reduced wheat planting. Additionally, although we found that the increase in grain subsidy payments for contracted farmland did not increase the farmland rental price, we still need more evidence to investigate who became the beneficiaries of the subsidy reform. Therefore, future research is required to answer the following questions empirically. (1) What are the impacts of China's grain subsidy reform on large-scale farms? (2) Will smallholder farms produce more cash crops or vegetables after the subsidy reform?

(3) Who benefit more from the subsidy reform, smallholder farms or large farms?

\section{Conclusions}

In summary, we used the 2013-2015 Survey for Agriculture and Village Economy (SAVE) data and a difference-in-difference (DID) approach to empirically investigate the impact of China's grain subsidy reform on the land use of smallholder farms. Our study reveals three main conclusions. First, there is a negative impact of grain subsidy reform on the wheat-sown area. Influenced by the grain subsidy reform, a smallholder farm in HuangHuai-Hai Plain would reduce $25 \%$ of its wheat-sown area. Second, the impact of subsidy reform is heterogeneous in scale. The smaller the farm, the greater the effect. Third, the impact pathway of China's grain subsidy reform is that smallholder farms might transfer their lands to large-scale farmers or cooperatives and thus decrease or terminate their grain production. At the end of 2013, the primary goal of China's agriculture policy was set to ensure basic self-sufficiency of grains and absolute security of food grains [65,66]. China's grain subsidy would like to be more precise and more focused on food security goals. Considering the fact that nearly $98 \%$ of farms in China are smaller than 2 ha $[3,6]$, China can strengthen its food security only if farm size is successfully increased. Thus, how to increase farm size through subsidy programs would be an essential issue in future researches.

Author Contributions: Conceptualization, N.Z.; methodology, X.H. and N.Z.; software, P.X. and X.H.; data curation, P.X.; writing-original draft preparation, X.H. and P.X.; writing-review and editing, X.H. and N.Z.; visualization, X.H. and P.X.; supervision, N.Z.; project administration, N.Z. All authors have read and agreed to the published version of the manuscript.

Funding: This research was funded by the National Natural Science Foundation of China (71703158), and the Agricultural Science and Technology Innovation Program of the Chinese Academy of Agricultural Sciences (ASTIP-IAED-2021-SR-09, ASTIP-IAED-2021-08). 
Data Availability Statement: The data presented in this study are available upon request from the corresponding author.

Conflicts of Interest: The authors declare no conflict of interest.

\section{Appendix A}

Table A1. The number of sample farms.

\begin{tabular}{cccc}
\hline Year & Hebei & Shandong & Henan \\
\hline 2013 & 152 & 168 & 395 \\
2014 & 171 & 140 & 387 \\
2015 & 190 & 101 & 359 \\
\hline
\end{tabular}

Table A2. Estimation results of the DID, OLS, and FE models.

\begin{tabular}{|c|c|c|c|}
\hline Variable & $\begin{array}{l}\text { DID4 } \\
\text { (1) }\end{array}$ & $\begin{array}{l}\text { OLS } \\
(2)\end{array}$ & $\begin{array}{l}\text { FE } \\
\text { (3) }\end{array}$ \\
\hline \multicolumn{4}{|l|}{ Dependent variable: $\ln W A$} \\
\hline$D_{i} \times T_{t}$ & $-0.28^{* *}$ & & \\
\hline$D_{i}$ & $\begin{array}{l}0.10 \\
(0.14)\end{array}$ & & \\
\hline$T_{t}$ & $\begin{array}{l}0.18^{* * *} \\
(0.07)\end{array}$ & $\begin{array}{l}-0.04 \\
(0.05)\end{array}$ & $\begin{array}{l}-0.03 \\
(0.03)\end{array}$ \\
\hline $\ln L B$ & $\begin{array}{c}-0.18 \\
(0.07)\end{array}$ & $\begin{array}{c}-0.29^{* * *} \\
(0.05)\end{array}$ & $\begin{array}{c}-0.14 \\
(0.05)\end{array}$ \\
\hline TRAC & $\begin{array}{l}0.34^{* *} \\
(0.12)\end{array}$ & $\begin{array}{l}0.20 \text { * } \\
(0.07)\end{array}$ & $\begin{array}{l}-0.02 \\
(0.02) \\
(0.06)\end{array}$ \\
\hline$A G E$ & $\begin{array}{l}0.06^{* *} \\
(0.02)\end{array}$ & $\begin{array}{l}0.04^{* *} \\
(0.01)\end{array}$ & $\begin{array}{c}0.01 \\
(0.01)\end{array}$ \\
\hline$A G E^{2}$ & $\begin{array}{l}-0.00^{* *} \\
(0.00)\end{array}$ & $\begin{array}{l}-0.00^{* *} \\
(0.00)\end{array}$ & $\begin{array}{l}-0.00 \\
(0.00)\end{array}$ \\
\hline$E D U$ & $-0.08^{* *}$ & $\begin{array}{c}-0.07 \\
(0.03)\end{array}$ & $\begin{array}{l}-0.03 \\
(0.02)\end{array}$ \\
\hline$E D U^{2}$ & $\begin{array}{l}0.01^{* *} \\
(0.00)\end{array}$ & $\begin{array}{l}0.01^{* *} \\
(0.00)\end{array}$ & $\begin{array}{l}0.00^{*} \\
(0.00)\end{array}$ \\
\hline$A G T$ & $\begin{array}{l}0.03 \\
(0.07)\end{array}$ & $\begin{array}{l}0.08 \\
(0.06)\end{array}$ & $\begin{array}{c}0.03 \\
(0.04)\end{array}$ \\
\hline Constant term & $\begin{array}{c}0.43 \\
(0.54)\end{array}$ & $\begin{array}{c}1.29^{* * *} \\
(0.33)\end{array}$ & $\begin{array}{c}1.77^{* * * *} \\
(0.38)\end{array}$ \\
\hline $\mathrm{N}$ & 833 & 2063 & 2063 \\
\hline
\end{tabular}

Notes: Cluster robust (town level) standard errors in parentheses; ${ }^{* * *} p<0.01,{ }^{* *} p<0.05,{ }^{*} p<0.10$.

Table A3. Estimation results of the impacts of subsidy reform on the amount of outflow land area and land tenure.

\begin{tabular}{ccc}
\hline & The Amount of Outflow Land Area & Land Tenure \\
\hline \multirow{2}{*}{$D_{i} \times T_{t}$} & $0.17^{* * *}$ & 0.10 \\
& $(0.04)$ & $(0.09)$ \\
$D_{i}$ & $-0.15^{* * *}$ & 0.10 \\
& $(0.02)$ & $(0.09)$ \\
$T_{t}$ & -0.11 & $38.89^{* * *}$ \\
& $(0.00)$ & $(0.70)$ \\
Constant term & $(0.10)$ & 118.17 \\
& $0.26^{* * *}$ & $(0.70)^{* * *}$ \\
\hline $\mathrm{N}$ & $(0.10)$ & 2063 \\
\hline
\end{tabular}

Notes: Cluster robust (town level) standard errors in parentheses; ${ }^{* * *} p<0.01$. 


\section{References}

1. OECD. Innovation, Agricultural Productivity and Sustainability in China; OECD Publishing: Paris, France, 2018.

2. Anderson, K. From taxing to subsidizing farmers in China post-1978. China Agric. Econ. Rev. 2018, 10, 36-47. [CrossRef]

3. Rapsomanikis, G. The Economic Lives of Smallholder Farmers: An Analysis Based on Household Data from Nine Countries; Food and Agriculture Organization of the United Nations: Rome, Italy, 2015.

4. Huang, J.; Ding, J. Institutional innovation and policy support to facilitate small-scale farming transformation in China. Agric. Econ. 2016, 47, 227-237. [CrossRef]

5. Ma, M.; Sexton, R.J. Modern agricultural value chains and the future of smallholder farming systems. Agric. Econ. 2021, 52, 591-606. [CrossRef]

6. The State Concil Information Office of the People's Republic of China. Available online: http://www.scio.gov.cn/xwfbh/xwbfbh/ wqfbh/39595/39965/wz39967/Document/1648043/1648043.htm (accessed on 22 May 2021).

7. Chen, Z.; Huffman, W.E.; Rozelle, S. Inverse Relationship between Productivity and Farm Size: The Case of China. Contemp. Econ. Policy 2010, 29, 580-592. [CrossRef]

8. Wu, Y.; Xi, X.; Tang, X.; Luo, D.; Gu, B.; Lam, S.K.; Vitousek, P.M.; Chen, D. Policy distortions, farm size, and the overuse of agricultural chemicals in China. Proc. Natl. Acad. Sci. USA 2018, 115, 7010-7015. [CrossRef] [PubMed]

9. Yan, J.; Chen, C.; Hu, B. Farm size and production efficiency in Chinese agriculture: Output and profit. China Agric. Econ. Rev. 2019, 11, 20-38. [CrossRef]

10. Zhang, X.; Yu, X.; Tian, X.; Geng, X.; Zhou, Y. Farm size, inefficiency, and rice production cost in China. J. Prod. Anal. 2019, 52, 57-68. [CrossRef]

11. Wu, H.; Hao, H.; Lei, H.; Ge, Y.; Shi, H.; Song, Y. Farm Size, Risk Aversion and Overuse of Fertilizer: The Heterogeneity of Large-Scale and Small-Scale Wheat Farmers in Northern China. Land 2021, 10, 111. [CrossRef]

12. Garrone, M.; Emmers, D.; Olper, A.; Swinnen, J. Jobs and agricultural policy: Impact of the common agricultural policy on EU agricultural employment. Food Policy 2019, 87, 101744. [CrossRef]

13. Espinosa, M.; Louhichi, K.; Perni, A.; Ciaian, P. EU-Wide Impacts of the 2013 CAP Direct Payments Reform: A Farm-Level Analysis. Appl. Econ. Perspect. Policy 2019, 42, 695-715. [CrossRef]

14. Baráth, L.; Fertő, I.; Bojnec, Š. The Effect of Investment, LFA and Agri-environmental Subsidies on the Components of Total Factor Productivity: The Case of Slovenian Farms. J. Agric. Econ. 2020, 71, 853-876. [CrossRef]

15. Jayne, T.S.; Rashid, S. Input subsidy programs in sub-Saharan Africa: A synthesis of recent evidence. Agric. Econ. 2013, 44, 547-562. [CrossRef]

16. National Bureau of Statistics of China (NBSC). China Statistical Yearbook 2020; China Statistics Press: Beijing, China, 2020.

17. OECD. Agricultural Support Estimates, 2020 ed.; OECD Publishing: Paris, France, 2018.

18. Huang, J.; Yang, G. Understanding recent challenges and new food policy in China. Glob. Food Secur. 2017, 12, 119-126. [CrossRef]

19. Yi, F.; Lu, W.; Zhou, Y. Cash transfers and multiplier effect: Lessons from the grain subsidy program in China. China Agric. Econ. Rev. 2016, 8, 81-99. [CrossRef]

20. Zhan, S. Riding on self-sufficiency: Grain policy and the rise of agrarian capital in China. J. Rural. Stud. 2017, 54, 151-161. [CrossRef]

21. Huang, J.; Wang, X.; Rozelle, S. The subsidization of farming households in China's agriculture. Food Policy 2013, 41, 124-132. [CrossRef]

22. Gale, F.; Lohmar, B.; Tuan, F. China's New Farm. Subsidies; United States Department of Agriculture: Washington, DC, USA, 2005.

23. Yi, F.; Sun, D.; Zhou, Y. Grain subsidy, liquidity constraints and food security-Impact of the grain subsidy program on the grain-sown areas in China. Food Policy 2015, 50, 114-124. [CrossRef]

24. MOF and MOA. Guiding Opinions on Adjusting and Improving the Three Subsidy Policies for Agriculture. Available online: http:/ / www.moa.gov.cn/nybgb/2015/qi/201712/t20171219\$backslash\$_6103732.htm (accessed on 12 January 2021).

25. Henan Province Department of Finance and Henan Province Department of Agriculture. Guiding Opinions on Adjusting and Improving the Three Subsidy Policies for Agriculture. Available online: http://czt.henan.gov.cn/2015/08-14/1059667.html (accessed on 12 January 2021).

26. Yi, F.; McCarl, B. Increasing the effectiveness of the Chinese grain subsidy: A quantitative analysis. China Agric. Econ. Rev. 2018, 10, 538-557. [CrossRef]

27. Shandong Province Department of Finance and Shandong Province Department of Agriculture. Guiding Opinions on Adjusting and Improving the Three Subsidy Policies for Agriculture. Available online: http://www.jimo.gov.cn/n28356077/n6035/161121 142401018218.html (accessed on 12 January 2021).

28. Wang, J.; Zhang, L.; Ouyang, R. China's Food Security in the past 40 Years of Reform and Opening-up: Achievements, Problems and Suggestion. Issues Agric. Econ. 2018, 39, 14-18.

29. Heerink, N.; Kuiper, M.; Shi, X. China's New Rural Income Support Policy: Impacts on Grain Production and Rural Income Inequality. China World Econ. 2006, 14, 58-69. [CrossRef]

30. Chen, Z.X.; Zhu, X.H.; Zhang, Z.G.; Song, L.N. Grain subsidy, grain orders financing and farmers' grain production. Agro. Food Ind. Hi-Tech. 2016, 27, 28-35.

31. Huang, J.; Wang, X.; Zhi, H.; Huang, Z.; Rozelle, S. Subsidies and distortions in China's agriculture: Evidence from producer-level data*. Aust. J. Agric. Resour. Econ. 2011, 55, 53-71. [CrossRef] 
32. Jiarong, Q.; Shoichi, I.; Yueying, M.; Zhijun, Z.; Xuejun, W. The role of subsidy policies in achieving grain self-sufficiency in China: A partial equilibrium approach. Agric. Econ. (Zemědělská ekonomika) 2018, 64, 23-35. [CrossRef]

33. Huang, K.; Yan, W.; Huang, J. Agricultural subsidies retard urbanisation in China. Aust. J. Agric. Resour. Econ. 2020, 64, 1308-1327. [CrossRef]

34. Meng, L. Can grain subsidies impede rural-urban migration in hinterland China? Evidence from field surveys. China Econ. Rev. 2012, 23, 729-741. [CrossRef]

35. Zhang, D.; Wang, H.; Lou, S. Research on grain production efficiency in China's main grain-producing areas from the perspective of grain subsidy. Environ. Technol. Innov. 2021, 22, 101530. [CrossRef]

36. Tian, Q.; Holland, J.H.; Brown, D.G. Social and economic impacts of subsidy policies on rural development in the Poyang Lake Region, China: Insights from an agent-based model. Agric. Syst. 2016, 148, 12-27. [CrossRef]

37. Zou, B.; Mishra, A.K.; Luo, B. Grain subsidy, off-farm labor supply and farmland leasing: Evidence from China. China Econ. Rev. 2019, 62, 101293. [CrossRef]

38. Guo, S.; Lv, X.; Hu, X. Farmers' land allocation responses to the soybean rejuvenation plan: Evidence from "typical farm" in Jilin, China. China Agric. Econ. Rev. 2021, 13, 705-719. [CrossRef]

39. Zhang, J.; Mishra, A.K.; Hirsch, S.; Li, X. Factors affecting farmland rental in rural China: Evidence of capitalization of grain subsidy payments. Land Use Policy 2020, 90, 104275. [CrossRef]

40. Heckman, J.J.; Smith, J.A. Assessing the Case for Social Experiments. J. Econ. Perspect. 1995, 9, 85-110. [CrossRef]

41. Heckman, J.J.; Ichimura, H.; Todd, P.E. Matching as An Econometric Evaluation Estimator: Evidence from Evaluating a Job Training Programme. Rev. Econ. Stud. 1997, 64, 605-654. [CrossRef]

42. Han, X.; Yang, S.; Chen, Y.; Wang, Y. Urban segregation and food consumption. China Agric. Econ. Rev. 2019, 11, 583-599. [CrossRef]

43. Xue, P.; Han, X.; Elahi, E.; Zhao, Y.; Wang, X. Internet Access and Nutritional Intake: Evidence from Rural China. Nutrients 2021, 13, 2015. [CrossRef] [PubMed]

44. Imbens, G.W.; Lemieux, T. Regression discontinuity designs: A guide to practice. J. Econ. 2008, 142, 615-635. [CrossRef]

45. Chen, Q.; Deng, T.; Bai, J.; He, X. Understanding the retirement-consumption puzzle through the lens of food consumption-fuzzy regression-discontinuity evidence from urban China. Food Policy 2017, 73, 45-61. [CrossRef]

46. Dimick, J.B.; Ryan, A.M. Methods for Evaluating Changes in Health Care Policy. JAMA 2014, 312, 2401-2402. [CrossRef]

47. Card, D.; Krueger, A. Minimum Wages and Employment: A Case Study of the Fast Food Industry in New Jersey and Pennsylvania. Am. Econ. Rev. 1993, 84, 772-793. [CrossRef]

48. Chen, Y.; Fan, Z.; Gu, X.; Zhou, L.-A. Arrival of Young Talent: The Send-Down Movement and Rural Education in China. Am. Econ. Rev. 2020, 110, 3393-3430. [CrossRef]

49. Petrick, M.; Zier, P. Regional employment impacts of Common Agricultural Policy measures in Eastern Germany: A difference-indifferences approach. Agric. Econ. 2010, 42, 183-193. [CrossRef]

50. Takayama, T.; Hashizume, N.; Nakatani, T. Impact of direct payments on agricultural land use in less-favoured areas: Evidence from Japan. Eur. Rev. Agric. Econ. 2019, 47, 157-177. [CrossRef]

51. Wang, A.; Lin, W.; Liu, B.; Wang, H.; Xu, H. Does Smart City Construction Improve the Green Utilization Efficiency of Urban Land? Land 2021, 10, 657. [CrossRef]

52. Lyu, L.; Gao, Z.; Long, H.; Wang, X.; Fan, Y. Farmland Use Transition in a Typical Farming Area: The Case of Sihong County in the Huang-Huai-Hai Plain of China. Land 2021, 10, 347. [CrossRef]

53. Shi, W.; Tao, F.; Liu, J. Changes in quantity and quality of cropland and the implications for grain production in the Huang-HuaiHai Plain of China. Food Secur. 2012, 5, 69-82. [CrossRef]

54. O'Donoghue, E.J.; Whitaker, J.B. Do Direct Payments Distort Producers' Decisions? An Examination of the Farm Security and Rural Investment Act of 2002. Appl. Econ. Perspect. Policy 2010, 32, 170-193. [CrossRef]

55. Simonet, G.; Subervie, J.; Ezzine-De-Blas, D.; Cromberg, M.; Duchelle, A.E. Effectiveness of a REDD+ Project in Reducing Deforestation in the Brazilian Amazon. Am. J. Agric. Econ. 2018, 101, 211-229. [CrossRef]

56. Helming, J.; Tabeau, A. The economic, environmental and agricultural land use effects in the European Union of agricultural labour subsidies under the Common Agricultural Policy. Reg. Environ. Chang. 2017, 18, 763-773. [CrossRef]

57. Ciaian, P. Land use changes in the EU: Policy and macro impact analysis. Agric. Econ. (Zemědělská ekonomika) 2008, 53, 565-579. [CrossRef]

58. Tzanopoulos, J.; Jones, P.J.; Mortimer, S.R. The implications of the 2003 Common Agricultural Policy reforms for land-use and landscape quality in England. Landsc. Urban. Plan. 2012, 108, 39-48. [CrossRef]

59. Tranter, R.; Swinbank, A.; Wooldridge, M.; Costa, L.; Knapp, T.; Little, G.; Sottomayor, M. Implications for food production, land use and rural development of the European Union's Single Farm Payment: Indications from a survey of farmers' intentions in Germany, Portugal and the UK. Food Policy 2007, 32, 656-671. [CrossRef]

60. Gardner, B.; Hardie, I.; Parks, P.J. United States Farm Commodity Programs and Land Use. Am. J. Agric. Econ. 2010, 92, 803-820. [CrossRef]

61. Lopez, R.A.; He, X.; De Falcis, E. What Drives China's New Agricultural Subsidies? World Dev. 2017, 93, 279-292. [CrossRef]

62. Ciaian, P.; Swinnen, J. Land Market Imperfections and Agricultural Policy Impacts in the New EU Member States: A Partial Equilibrium Analysis. Am. J. Agric. Econ. 2006, 88, 799-815. [CrossRef] 
63. Lin, W.; Huang, J. Impacts of agricultural incentive policies on land rental prices: New evidence from China. Food Policy 2021, 104, 102125. [CrossRef]

64. Price Division of National Development and Reform Commission. Compilation of the National Agricultural Costs and Returns 2019; China Statistics Press: Beijing, China, 2019.

65. Chen, X. The core of China's rural revitalization: Exerting the functions of rural area. China Agric. Econ. Rev. 2019, 12, 1-13. [CrossRef]

66. Han, J. Prioritizing agricultural, rural development and implementing the rural revitalization strategy. China Agric. Econ. Rev. 2019, 12, 14-19. [CrossRef] 